\title{
Adaptation of calcium absorption during treatment of nutritional rickets in Nigerian children
}

\author{
Gloria E. Oramasionwu ${ }^{1}$, Tom D. Thacher ${ }^{2} \dagger$, Sunday D. Pam ${ }^{3}$, John M. Pettifor ${ }^{4}$ and Steven A. Abrams ${ }^{1}$ \\ ${ }^{1}$ Department of Pediatrics, USDA/ARS Children's Nutrition Research Center, Baylor College of Medicine and Texas Children's \\ Hospital, Houston, Texas 77030, USA \\ ${ }^{2}$ Department of Family Medicine, Jos University Teaching Hospital, P.M.B. 2076, Jos, Nigeria \\ ${ }^{3}$ Department of Paediatrics, University of Jos, P.M.B. 2084, Jos, Nigeria \\ ${ }^{4}$ MRC Mineral Metabolism Research Unit, Department of Paediatrics, University of the Witwatersrand and Chris Hani \\ Baragwanath Hospital, P O Bertsham 2013, South Africa
}

(Received 24 August 2007 - Revised 5 November 2007 - Accepted 14 November 2007 - First published online 15 January 2008)

Nutritional rickets in Nigerian children has been effectively treated with Ca supplementation. High values of Ca absorption efficiency have been observed in untreated children, but whether $\mathrm{Ca}$ absorption efficiency changes during treatment with $\mathrm{Ca}$ is unknown. Our objective in conducting this study was to identify the effect of $\mathrm{Ca}$ therapy on $\mathrm{Ca}$ absorptive efficiency in children with primary Ca-deficient nutritional rickets. Twelve children with radiographically active rickets, 2 to 14 years of age (median 39 months) participated in the study. We assessed dietary Ca intake via dietary recalls, and measured biochemical markers of $\mathrm{Ca}$ and vitamin $\mathrm{D}$ homeostasis. Fractional $\mathrm{Ca}$ absorption was measured using a dual tracer stable isotope method, before and after 2 weeks of treatment with $15.0 \mathrm{mmol}$ elemental Ca daily. Ten children had adequate urine collection for inclusion in the analysis. Usual dietary Ca intake was 4.2 (SD 1.0) $\mathrm{mmol} / \mathrm{d}$. The median Ca absorption prior to treatment was $72 \%$ (range $52-97 \%)$ and decreased significantly to $57 \%(31-84 \%)(P=0.004)$ after 2 weeks of supplementation. We conclude that Nigerian children with rickets adapt to $\mathrm{Ca}$ supplementation with a small decrease in $\mathrm{Ca}$ absorptive capacity, but retain very high absorptive levels during supplementation. Overall $\mathrm{Ca}$ absorption efficiency was comparable with that identified in other populations with low $\mathrm{Ca}$ intakes. These data demonstrate that although absorptive capacity is regulated by supplementation, recovery from rickets likely occurs through efficient use of both dietary and supplemental Ca.

Stable isotopes: Africa: Dietary Ca deficiency: Intestinal Ca absorption

Nutritional rickets continues to be a major paediatric concern in many developing countries including Nigeria, Bangladesh and Mongolia. While the aetiology of nutritional rickets in young children has usually been ascribed to vitamin D deficiency associated with prolonged breast feeding and lack of sunlight exposure or vitamin D supplementation, prior studies in Nigerian children suggest that inadequate $\mathrm{Ca}$ intake is the principal cause of nutritional rickets in this population $^{(1-3)}$. Ca supplementation, with or without vitamin D, produces healing of rickets in Nigerian children ${ }^{(4,5)}$. Limited Ca intake by children in the developing world often results from a lack of dairy products in the customary diet. Most people rely on grains, legumes and vegetables to meet the needs of the growing skeleton for $\mathrm{Ca}$. In addition, these customary diets often contain potential inhibitors of $\mathrm{Ca}$ absorption, such as phytates and oxalates. Consequently, the average daily $\mathrm{Ca}$ intake is commonly below $7.5 \mathrm{mmol}$ for children in developing countries.
$\mathrm{Ca}$ absorptive efficiency is regulated by $\mathrm{Ca}$ intake. This occurs by multiple mechanisms. Low $\mathrm{Ca}$ intakes lead both to increased vitamin $\mathrm{D}$ conversion to the active 1,25dihydroxyvitamin $\mathrm{D}$ form and to increased passive absorption of available Ca. Nonetheless, in the presence of high levels of dietary inhibitors and very low intakes, these mechanisms are inadequate to provide adequate $\mathrm{Ca}$ for skeletal growth. Although absorption efficiency is inversely related to the $\mathrm{Ca}$ load during a meal, little is known about the regulation of absorption efficiency over a period of supplementation in populations with usual low intakes. Concern may exist that decreased absorption would limit the efficacy of such interventions.

Clinical studies have demonstrated the efficacy of Ca supplementation in resolving rickets ${ }^{(4,5)}$. Thus, the use of supplements must lead to the absorption of enough bioavailable $\mathrm{Ca}$ to be beneficial. However, in designing intervention strategies, the effect of supplementation on the absorption of $\mathrm{Ca}$ 
from the diet must be considered and there are no data on this relationship.

The aim of the present study was to identify the effects of $\mathrm{Ca}$ therapy on $\mathrm{Ca}$ absorption efficiency in Nigerian children with nutritional rickets. We hypothesized that the high values of $\mathrm{Ca}$ absorption efficiency prior to the treatment of rachitic children would be maintained after supplemental Ca therapy.

\section{Experimental methods}

We recruited seventy-three children with bowleg or knockknee deformities characteristic of rickets by means of posters and word of mouth in the city of Jos, Nigeria. Based on our previous study in Nigerian children, we anticipated the mean fractional $\mathrm{Ca}$ absorption would be approximately 60 (SD 12) $\%$ at both the baseline and follow-up assessments ${ }^{(6)}$. We assumed the smallest clinically important difference in fractional $\mathrm{Ca}$ absorption to be $10 \%$ between the baseline and 2 -week assessments. A sample size of ten subjects would provide $80 \%$ power to detect such a difference with $95 \%$ confidence. Fifteen children were eligible and twelve children were enrolled to allow for possible data loss.

All subjects were interviewed and examined by one of the investigators and radiographs of the wrists and knees were obtained at the Jos University Teaching Hospital. Active rickets was defined as a radiographic score of at least 2 on a 10-point scale, where a score of 10 indicates the most severe rickets ${ }^{(7)}$. Children were offered enrolment if they had radiographically active rickets and the parent reported adequate bladder control, which was deemed necessary for a $24 \mathrm{~h}$ urine collection. Subjects were excluded if they had a chronic illness or were taking medications that might affect bone metabolism, including vitamin or mineral supplements. Informed written consent for the current study was obtained from a parent and the study was approved by the Investigational Review Board for Human Studies of Baylor College of Medicine and the Ethical Committee of Jos University Teaching Hospital. Subjects and their families were not given monetary compensation for their participation.

Baseline $\mathrm{Ca}$ intake was assessed from 24-h dietary recalls performed on two different days. We used a database constructed from food composition tables designed for African foodstuffs ${ }^{(8,9)}$. We measured each child's weight, height, triceps skinfold thickness and mid-upper arm circumference. Bone density of the forearm was measured with a Norland pDEXA (Model 476A110; Fort Atkinson, WI, USA) portable bone densitometer. Measurement sites included the area of minimal bone density of the ultradistal radius and ulna (primarily trabecular bone) and the distal one-third of the radius and ulna (primarily cortical bone). The instrument was set at standard precision and calibrated daily. Long-term precision of bone mineral content and areal density of a standard bone phantom were $\pm 0.017 \mathrm{~g}$ and $\pm 0.011 \mathrm{~g} / \mathrm{cm}^{2}$, respectively.

After an overnight fast, we admitted children to the Jos University Teaching Hospital for measurement of fractional $\mathrm{Ca}$ absorption using an established dual stable isotope technique ${ }^{(10)}$ (Fig. 1). Topical lidocaine/prilocaine $(2.5 \% / 2.5 \%)$ anaesthetic cream was applied over a peripheral arm vein at least $60 \mathrm{~min}$ prior to insertion of an intravenous butterfly needle. During the $60 \mathrm{~min}$ after application of the topical anaesthetic, each child voided to empty their bladder, then ate a typical Nigerian breakfast of maize porridge (pap), to which $0.5 \mathrm{mg} / \mathrm{kg}{ }^{44} \mathrm{Ca}$ and $2.5 \mathrm{mmol}$ elemental $\mathrm{Ca}$ was added as calcium carbonate.

The $\mathrm{Ca}$ content of the entire breakfast with the added $\mathrm{Ca}$ was estimated to be approximately $4.5 \mathrm{mmol}$. This intake was used for both the pre- and post-supplementation study. Thus, the Ca intake during the pre-supplementation study day itself was higher than the usual daily intake, but well below that during the Ca supplementation period. This approach provided a consistent evaluation of the $\mathrm{Ca}$ absorptive capacity of the subjects before and after the supplementation period.

Blood was collected for measurement of serum $\mathrm{Ca}, \mathrm{P}$, albumin, 25-hydroxyvitamin $\mathrm{D}$, alkaline phosphatase activity and parathyroid hormone (PTH). Subsequently, $0.12 \mathrm{mg} / \mathrm{kg}{ }^{42} \mathrm{Ca}$ in $2 \mathrm{ml}$ normal saline was given intravenously between $30 \mathrm{~min}$ and $2 \mathrm{~h}$ after ingestion of the oral isotope. All isotope samples were pre- and post-weighed to ensure accurate determination of isotope quantities. Urine was collected for $24 \mathrm{~h}$ following isotope administration. Total urine volume was recorded and $300 \mathrm{ml}$ aliquots were collected from each child's pooled urine, frozen at $-20^{\circ} \mathrm{C}$ and transported along with the frozen sera to Baylor College of Medicine for analysis.

Following completion of the baseline $24 \mathrm{~h}$ urine collection, all enrolled children were given chewable calcium carbonate tablets to provide $15.0 \mathrm{mmol}$ elemental $\mathrm{Ca}$ daily to be taken orally in two divided doses at meal times for the next $14 \mathrm{~d}$. After $14 \mathrm{~d}$ of Ca supplementation, enrolled children were readmitted for a second $\mathrm{Ca}$ absorption measurement. Compliance with $\mathrm{Ca}$ supplementation was assessed with pill counts. The procedures for isotope administration, serum collection and $24 \mathrm{~h}$ urine collection were identical to those of the baseline study. Children were not given the $15 \mathrm{mmol} \mathrm{Ca}$ supplementation during either admission, but only the $2.5 \mathrm{mmol}$ with breakfast (yielding a total $\mathrm{Ca}$ intake of approximately $4.5 \mathrm{mmol}$ when including the Ca present in the meal).

Ca therapy was continued for 6 months to allow time for complete healing of rickets to occur. Following 3 months of treatment, radiographs of the wrists and knees were repeated and bone density was measured.

All data were entered and analysed in Epi Info 2002 (CDC, Atlanta, GA, USA). Anthropometric indices were calculated with the nutritional anthropometry program of Epi Info using the CDC 2000 growth reference curves. Mean values are reported for normally distributed variables and median values for non-normally distributed variables. Correlation coefficients were calculated to quantify relationships between continuous variables. To compare mean values at different time points, the paired $t$ test in Excel 2003 (Microsoft, Redmond, WA, USA) was used for all comparisons other than the comparison of radiographic rachitic severity at baseline and 3 months, in which case the Wilcoxon rank test was used. All $P$ values quoted are for two-tailed tests.

\section{Results}

A total of seventy-three children with clinical characteristics of rickets (primarily leg deformities) underwent radiography of the wrists and knees. Of the seventy-three children with clinical rickets, fifteen had radiographically active rickets and twelve of these were enrolled. The three children who were not enrolled either did not have good bladder control or did 


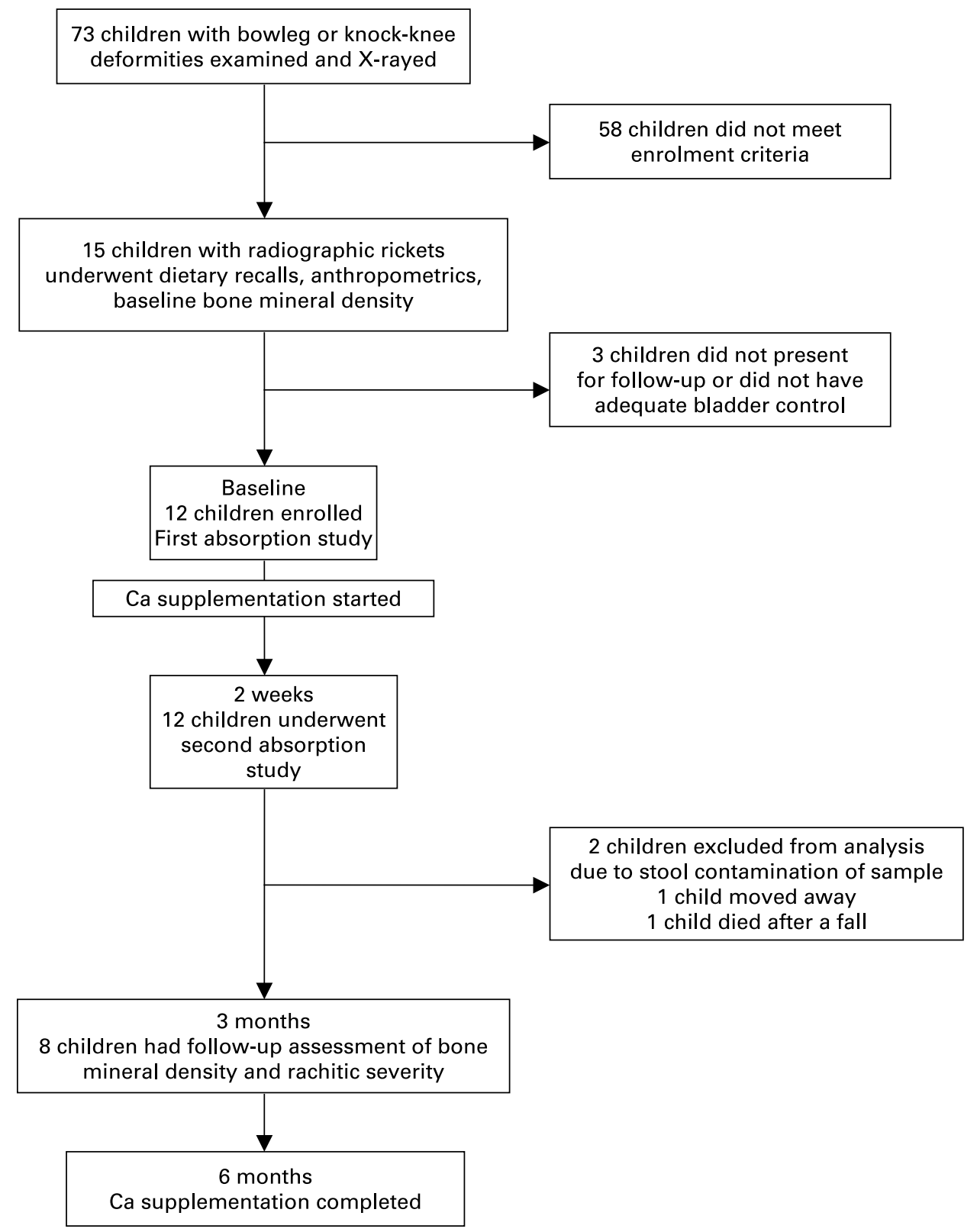

Fig. 1. Study profile. For details of subjects and procedures, see Experimental methods.

not return for follow-up appointments. Two enrolled children were excluded from the final analysis because their urine collections were poor (excess spillage or stool contamination), and one of them probably had incomplete intake of the oral isotope (she did not want to complete the maize pap containing the isotope). Characteristics of the remaining ten study subjects are shown in Table 1. One child died from a fall 2 months after enrolment and another moved away, accounting for the loss of two children at the 3-month follow-up visit.

The ages of most subjects were between 2 and 5 years (median age of 39 months, range 25 to 175 months), except for one 6 and one 14 year-old. None of the children was currently breast feeding. The baseline dietary $\mathrm{Ca}$ intake of the children was low with a mean daily $\mathrm{Ca}$ intake of 4.2 (SD 1.0) mmol. There was a trend for baseline values of 25-hydroxyvitamin $\mathrm{D}$ to be inversely related to the radiographic rickets score $(r-0.63 ; P=0 \cdot 06)$, although this relationship did not show statistical significance. There was also no relationship between values of 25-hydroxyvitamin D and forearm bone mineral density.

Baseline fractional $\mathrm{Ca}$ absorption efficiency was high, with a median value of $72 \%$ (range 52-97\%) and trended towards a significant inverse relationship to age $(r-0.60 ; P=0 \cdot 07)$. The relationship of absorption with age was significant when the logarithm of age was used $(r-0.69 ; P=0.03)$. Baseline $\mathrm{Ca}$ absorption was significantly positively related to the weight for age $\mathrm{z}$-score $(r 0.64, P=0.05)$ but not to the weight for height or height for age $\mathrm{z}$-scores. Baseline $\mathrm{Ca}$ absorption was inversely related to bone mineral density ( $r-0.71, P=0.02$ for the ultradistal wrist and $r-0.64$, $P=0.05$ for the distal one-third wrist). There was no significant relationship of baseline fractional $\mathrm{Ca}$ absorption with 
Table 1. Characteristics of ten Nigerian children with nutritional rickets $†$

(Median values and range for variables with skewed distribution. Mean values and standard deviations for variables with normal distribution)

\begin{tabular}{|c|c|c|c|c|c|c|c|}
\hline \multirow[b]{2}{*}{ Characteristic } & \multicolumn{3}{|c|}{ Baseline $(n 10)$} & \multicolumn{3}{|c|}{$\begin{array}{c}\text { 3-month follow up } \\
\text { (after Ca supplementation) } \\
(n 8)\end{array}$} & \multirow[b]{2}{*}{$P$ value } \\
\hline & Mean & SD & Range & Mean & SD & Range & \\
\hline Age (months) & $38 \cdot 7$ & & $24 \cdot 7-175$ & & & & \\
\hline \multicolumn{8}{|l|}{ Sex } \\
\hline Male & 5 & & & & & & \\
\hline Female & 5 & & & & & & \\
\hline Weight for age z-score & -1.5 & & -4.2 to -0.8 & $-1 \cdot 7$ & & -3.7 to -1.1 & 0.89 \\
\hline Weight $(\mathrm{kg})$ & $14 \cdot 2$ & $6 \cdot 2$ & & $15 \cdot 7$ & $6 \cdot 9$ & & \\
\hline Height for age z-score & $-2 \cdot 7$ & & -4.3 to -0.9 & $-2 \cdot 7$ & & -3.5 to -1.0 & 0.37 \\
\hline Weight for height z-score & -0.5 & $1 \cdot 0$ & & -0.2 & 1.0 & & 0.74 \\
\hline BMI $\left(\mathrm{kg} / \mathrm{m}^{2}\right)$ & $16 \cdot 1$ & 1.3 & & $16 \cdot 0$ & $1 \cdot 2$ & & 0.32 \\
\hline MAC for age z-score & $-1 \cdot 2$ & 1.0 & & & & & \\
\hline Dietary $\mathrm{Ca}$ intake $(\mathrm{mmol} / \mathrm{d})$ & 4.2 & $1 \cdot 0$ & & & & & \\
\hline Dietary $\mathrm{Ca}$ intake per $\mathrm{kg}$ body weight (mmol/kg per d) & 0.3 & 0.1 & & & & & \\
\hline
\end{tabular}

MAC, mean arm circumference.

${ }^{*} P$ values for the 3-month follow-up are only for the baseline $v$. 3-month comparison of eight children.

$\dagger$ For details of subjects and procedures, see Experimental methods.

dietary $\mathrm{Ca}$ intake $(r 0.04, P=0.91)$, sex (females $76 \%$ and males $70 \%, P=0.64)$, or radiographic score $(r-0.03$, $P=0.94)$. Furthermore, baseline fractional $\mathrm{Ca}$ absorption was also not related to serum 25-hydroxyvitamin $\mathrm{D}(r$ 0.22; $P=0.54)$ or PTH values $(r-0.37 ; P=0.29)$ and PTH values were unrelated to 25 -hydroxyvitamin $\mathrm{D}$ values.

After treatment with $15 \mathrm{mmol}$ elemental Ca daily over a 2-week period, the median fractional $\mathrm{Ca}$ absorption efficiency decreased from $72 \%$ (range $52-97 \%$ ) at baseline to $57 \%$ (range 31-84\%) (Table 2). The mean decline in fractional absorption was 20 (SD 18) \% (range -0.4 to $-58 \%$ ). The change in $\mathrm{Ca}$ absorption over the 2-week interval was not significantly related to age, sex, anthropometric indices, baseline $\mathrm{Ca}$ absorption, serum $\mathrm{Ca}$, alkaline phosphatase activity, 25-hydroxyvitamin D, PTH, bone density at the wrist or severity of radiographic score. The baseline low-normal serum $\mathrm{Ca}$, low serum $P$ and elevated alkaline phosphatase activity values were consistent with nutritional rickets. These values did not change significantly during the initial 2 -week treatment interval (Table 2).

Treatment compliance ranged from 82 to $96 \%$ of the supplied Ca tablets over the 3 months of follow up. In the subjects who had bone densitometry at the 3-month follow up, there was no relationship between the fractional $\mathrm{Ca}$ absorption at 2 weeks and the increase in bone mineral content or density (Table 2). However, there was a trend toward a greater increase in distal one-third radius and ulna bone mineral content among those with less severe baseline radiographic scores (or a lower score on the 10 point rickets radiographic scale) $(r-0.74 ; P=0.07)$, although these results were not statistically significant. This increase in bone density was unrelated to baseline alkaline phosphatase activity or to improvement in radiographic score with treatment.

\section{Discussion}

Children with rickets require much longer than 2 weeks for their bones to become mineralized and the metabolic demand for $\mathrm{Ca}$ should remain high until the bones achieve nearly complete mineralization. We found that within 2 weeks fractional $\mathrm{Ca}$ absorption decreased during $\mathrm{Ca}$ supplementation in Nigerian children with nutritional rickets. These findings are consistent with the known effects of increasing $\mathrm{Ca}$ intake on fractional $\mathrm{Ca}$ absorption in healthy adults and children ${ }^{(11,12)}$. Ca absorption in healthy adults has both a component that is saturable (vitamin $\mathrm{D}$ dependent) and a component proportional to intake ${ }^{(13)}$. The active component of $\mathrm{Ca}$ absorption is saturable and down regulated when $\mathrm{Ca}$ intake increases ${ }^{(14)}$. A possible explanation for the present findings of a reduction in fractional $\mathrm{Ca}$ absorption associated with $\mathrm{Ca}$ supplementation is that the active component of $\mathrm{Ca}$ absorption is down regulated in response to the reduction in 1,25-dihydroxyvitamin $\mathrm{D}$ concentration following improved $\mathrm{Ca}$ balance. Nigerian children with rickets therefore quickly adapt to an increased $\mathrm{Ca}$ intake. Active $\mathrm{Ca}$ transport in the duodenum is known to be down regulated when $\mathrm{Ca}$ intake increases ${ }^{(14)}$. By increasing $\mathrm{Ca}$ intake, the total amount of $\mathrm{Ca}$ absorbed increases, even though the fractional absorption declines.

In adolescent girls, an increased Ca intake (21.2 (SD 2.0) $\mathrm{mmol} / \mathrm{d}$ compared with $47.4(\mathrm{SD} 1.2) \mathrm{mmol} / \mathrm{d}$ ) reduced bone resorption by $32 \%$, resulting in enhanced retention of $\mathrm{Ca}$ in bone ${ }^{(15)}$. However, the fractional absorption of $\mathrm{Ca}$ in these girls did not change over a 1-month interval. This lack of change in fractional $\mathrm{Ca}$ absorption may be because the lower $\mathrm{Ca}$ dose of 21.2 (SD 2.0 ) $\mathrm{mmol} / \mathrm{d}$ is already relatively high (unlike in the current study) and fractional $\mathrm{Ca}$ intake was already relatively low at $48 \%$, leaving little room for a further decrease in fractional $\mathrm{Ca}$ absorption. These results differ from those of a study in young children (3-5 years old), which are consistent with the present findings, and demonstrated a $12.5 \%$ decline in fractional absorption when dietary $\mathrm{Ca}$ intake was increased more than two-fold ${ }^{(16)}$. This decline in fractional $\mathrm{Ca}$ absorption might be explained by the effect that doubling the $\mathrm{Ca}$ content of the test meal had on the intestinal $\mathrm{Ca}$ absorption process, which probably 
Table 2. Impact of Ca supplementation on Ca absorption efficiency and other markers of rickets in ten children†

(Median values and range for variables with skewed distribution. Mean values and standard deviations for variables with normal distribution)

\begin{tabular}{|c|c|c|c|c|c|c|c|c|c|c|}
\hline \multirow[b]{2}{*}{ Characteristic } & \multicolumn{3}{|c|}{$\begin{array}{l}\text { Baseline } \\
(n 10)\end{array}$} & \multicolumn{3}{|c|}{$\begin{array}{l}\text { After } 2 \text { weeks of } \mathrm{Ca} \\
\qquad(n 10)\end{array}$} & \multicolumn{3}{|c|}{$\begin{array}{l}\text { 3-month follow up } \\
(n 8)\end{array}$} & \multirow[b]{2}{*}{$P$ value } \\
\hline & Mean & SD & Range & Mean & $\mathrm{SD}$ & Range & Mean & SD & Range & \\
\hline Median Ca absorptive efficiency (\%) & 72 & & $52-97$ & 57 & & $31-84$ & & & & 0.004 \\
\hline Radiographic rachitic severity $\ddagger$ & 4.4 & $2 \cdot 4$ & & & & & 3.1 & $2 \cdot 3$ & & 0.002 \\
\hline \multicolumn{11}{|l|}{ Bone densitometry } \\
\hline \multicolumn{11}{|l|}{ Ultradistal radius and ulna } \\
\hline Areal bone density $\left(\mathrm{g} / \mathrm{cm}^{2}\right)$ & 0.129 & & $0.106-0.216$ & & & & 0.162 & & $0.119-0.240$ & 0.04 \\
\hline Bone mineral content $(\mathrm{g})$ & 0.272 & & $0.192-0.311$ & & & & 0.334 & & $0.268-0.596$ & 0.007 \\
\hline Bone area $\left(\mathrm{cm}^{2}\right)$ & $2 \cdot 10$ & & $1.81-2.72$ & & & & $2 \cdot 11$ & & $1.99-2.89$ & 0.007 \\
\hline \multicolumn{11}{|l|}{ Distal $1 / 3$ radius and ulna } \\
\hline Areal bone density $\left(\mathrm{g} / \mathrm{cm}^{2}\right)$ & 0.210 & & $0.154-0.370$ & & & & 0.238 & & $0.162-0.394$ & 0.24 \\
\hline Bone mineral content $(\mathrm{g})$ & 0.382 & & $0.261-0.822$ & & & & 0.409 & & $0.293-0.889$ & 0.40 \\
\hline Bone area $\left(\mathrm{cm}^{2}\right)$ & 1.89 & & $1.69-2.43$ & & & & 1.89 & & $1.72-2.50$ & 0.99 \\
\hline \multicolumn{11}{|l|}{ Serum } \\
\hline $\mathrm{Ca}(\mathrm{mmol} / \mathrm{l})$ & $2 \cdot 14$ & 0.14 & & $2 \cdot 11$ & 0.19 & & & & & 0.36 \\
\hline $\mathrm{P}(\mathrm{mmol} / \mathrm{l})$ & 0.92 & 0.20 & & 0.93 & 0.19 & & & & & 0.63 \\
\hline Alkaline phosphatase (U/l) & 735 & 229 & & 798 & 311 & & & & & 0.34 \\
\hline 25-Hydroxyvitamin D ( $\mu \mathrm{mol} / \mathrm{l})$ & 39.5 & $12 \cdot 5$ & & & & & & & & \\
\hline PTH $(p g / m l)$ & 292 & 156 & & & & & & & & \\
\hline
\end{tabular}

PTH, parathyroid hormone.

${ }^{\star} P$ values for the 3-month follow-up are only for the baseline $v$. 3-month comparison of eight children.

$\dagger$ For details of subjects and procedures, see Experimental methods.

$\ddagger$ Based on a validated 10-point score with 10 representing the most severe rickets (comparison based on Wilcoxon rank test).

switched from being a purely active process to one that was dependent on both active and passive processes ${ }^{(16)}$. Also consistent with the present findings are results from a study of African American and Caucasian pubertal girls, which found that fractional $\mathrm{Ca}$ absorption decreased from $63.8 \%$ on a low $\mathrm{Ca}$ intake of $9.7 \mathrm{mmol} / \mathrm{d}$ to $44.9 \%$ on a high $\mathrm{Ca}$ intake of $31.5 \mathrm{mmol} / \mathrm{d}^{(17)}$.

The high values of fractional $\mathrm{Ca}$ absorption in our subjects indicate that 1,25-dihydroxyvitamin $\mathrm{D}$ was sufficient to stimulate $\mathrm{Ca}$ absorption despite less than optimal 25-hydroxyvitamin $\mathrm{D}$ status. The high values of fractional $\mathrm{Ca}$ absorption that we observed may result not only from rachitic disease associated with high 1,25-dihydroxyvitamin D concentrations in our subjects but also from ethnic factors. Despite lower values of 25-hydroxyvitamin $\mathrm{D}$, fractional $\mathrm{Ca}$ absorption has been found to be greater in black than in white girls between the ages of 5 and 16 years ${ }^{(18)}$. In studies of children in both the United States and Nigeria, we have observed no relationship between 25-hydroxyvitamin D concentrations and fractional $\mathrm{Ca}$ absorption $^{(6,19)}$. The fractional absorption values in this study are similar to those we have found previously in Nigerian children, suggesting a maximal absorption fraction of about $70-80 \%$, regardless of 25 -hydroxyvitamin $\mathrm{D}$ values. The lack of a relationship between baseline fractional $\mathrm{Ca}$ and 25-hydroxyvitamin $\mathrm{D}$ level in the present study is also consistent with the previous study ${ }^{(6)}$.

In our previous study, baseline fractional $\mathrm{Ca}$ absorption in children with rickets and in matched control children was high $\left(61 \%\right.$ and $63 \%$, respectively ${ }^{(6)}$. After 12 months following treatment with $\mathrm{Ca}$ and documented healing of rickets, mean values of fractional $\mathrm{Ca}$ absorption $(81 \%)$ in rachitic children were significantly greater than those prior to treatment. However, unlike the current study, the children with healed rickets were not taking supplemental $\mathrm{Ca}$ at the time of the 12-month study. Interestingly, the severity of rickets did not correlate with higher baseline fractional absorption. For ethical reasons, our current study was not performed with a control group of children with rickets who did not receive treatment for the duration of the study period; therefore, the observed decrease in fractional $\mathrm{Ca}$ absorption may be secondary to confounding factors that change the measurement of $\mathrm{Ca}$ absorption over time.

The body adapts to an increased $\mathrm{Ca}$ intake by down regulating $\mathrm{Ca}$ absorptive efficiency to less than the presumably maximal values observed prior to treatment. Nigerian children with rickets are likely to adapt quickly to an increased $\mathrm{Ca}$ intake. Active $\mathrm{Ca}$ transport in the duodenum is known to be down regulated when $\mathrm{Ca}$ intake increases ${ }^{(18)}$. Chinese children with daily $\mathrm{Ca}$ intakes of $12.5 \mathrm{mmol}$ or less had higher fractional $\mathrm{Ca}$ absorption than those with daily intakes over $12.5 \mathrm{mmol}(63 \% \text { and } 55 \% \text {, respectively })^{(20)}$. In another study by the same author, baseline fractional $\mathrm{Ca}$ absorption declined from $61 \%$ to $56 \%$ after 6 months of Ca supplementation in Chinese children, but the difference was not significant ${ }^{(21)}$. It is important to note that although the fractional $\mathrm{Ca}$ absorption declined over the 2 -week treatment interval in our subjects, the estimated total amount of $\mathrm{Ca}$ absorbed increased more than three-fold due to the increased $\mathrm{Ca}$ intake associated with the addition of $\mathrm{Ca}$ supplements.

We did not find any relationship between the fractional $\mathrm{Ca}$ absorption at 2 weeks and the increase in bone mineral content or density for the eight subjects who were available for the 3-month follow up, although there was a statistically insignificant trend towards increased bone mineral content in those children whose rickets was less severe by our radiographic parameters. We did find that, overall, these eight children had a statistically significant improvement in their radiographic rickets severity score after 3 months of daily $\mathrm{Ca}$ 
supplementation $(4 \cdot 4 \pm 2 \cdot 4$ to $3 \cdot 1 \pm 2 \cdot 3, P<0.001)$ as well as improvement in the bone mineral density and bone mineral content of the ultradistal radius and ulna (Table 2). These findings might imply that $\mathrm{Ca}$ supplementation ultimately improves the course of rickets; however, we are not able to say that this improvement in rickets is related to the level of fractional $\mathrm{Ca}$ absorption. With only eight subjects left at the 3-month follow up there is the possibility that we did not have the power to detect a relationship if one truly did exist.

We cannot determine the exact absorptive efficiency from the Ca supplement itself. Since the supplement is not taken with dietary inhibitors such as might be found in usual Nigerian meals and the supplement is given over the span of the day, it is likely that absorption efficiency is high. Even if the absorption efficiency of the $15.0 \mathrm{mmol}$ supplement is $20 \%$ less than the usual $\mathrm{Ca}$ absorption, the total amount of $\mathrm{Ca}$ absorbed would more than double from the pre-supplement total $\mathrm{Ca}$ absorbed.

Also, the extent to which our measured absorption efficiency from the test meal represents a child's fractional $\mathrm{Ca}$ absorption is based on the extent to which the $\mathrm{Ca}$ proportion in our test meal is representative of the average $\mathrm{Ca}$ proportion in that child's daily diet. The test meal we provided was higher than the children's average baseline $\mathrm{Ca}$ intake, but still very low in $\mathrm{Ca}$ and likely reasonably represented usual $\mathrm{Ca}$ intake. Because most of the $\mathrm{Ca}$ in the diet of children in Nigeria is in the form of plant foods and grains, there is no way to accurately trace this intake and thus a true absolute measure of absorption is not possible from the food sources without intrinsic labelling of the food sources.

In conclusion, we found that Nigerian children with nutritional rickets decrease their $\mathrm{Ca}$ absorptive efficiency slightly in response to $\mathrm{Ca}$ supplementation. However, the overall maintenance of a high efficiency of $\mathrm{Ca}$ absorption in the face of supplementation indicates that such supplementation strategies do not impair the native absorptive capacity and that children with rickets maintain a normal pattern of $\mathrm{Ca}$ homeostasis.

\section{Acknowledgements}

The authors are grateful to Dr Christian O. Isichei for his assistance in processing the serum samples and to Mrs Rhoda Yakubu and Mrs Bernice Nzekwe for their assistance with the $24 \mathrm{~h}$ urine collection. The authors have no disclosure to make with regard to any advisory board affiliations during the conduct of this research or financial or personal relationships with any company or organization that sponsored the research. This work was supported in part by a grant from the Winters Foundation.

\section{References}

1. Pfitzner MA, Thacher TD, Pettifor JM, Zoakah AI, Lawson JO, Isichei CO \& Fischer PR (1998) Absence of vitamin D deficiency in young Nigerian children. J Pediatr 133, 740-744.

2. Thacher TD (2003) Calcium-deficiency rickets. In Vitamin D and Rickets. Endocrine Development, vol. 6, pp. 105-125 [Z Hochberg, editor]. Basel: Karger.
3. Okonofua F, Gill DS, Alabi ZO, Thomas M, Bell JL \& Dandona P (1991) Rickets in Nigerian children: a consequence of calcium malnutrition. Metabolism 40, 209-213.

4. Thacher TD, Fischer PR, Pettifor JM, Lawson JO, Isichei CO, Reading JC \& Chan GM (1999) A comparison of Ca, vitamin $\mathrm{D}$, or both for nutritional rickets in Nigerian children. $N$ Engl J Med 341, 563-568.

5. Oginni LM, Sharp CA, Badru OS, Risteli J, Davie MWJ \& Worsfold M (2003) Radiological and biochemical resolution of nutritional rickets with Ca. Arch Dis Child 88, 812-817.

6. Graff M, Thacher TD, Fischer PR, Stadler D, Pam SD, Pettifor JM, Isichei CO \& Abrams SA (2004) Calcium absorption in Nigerian children with rickets. Am J Clin Nutr 80, 1415-1421.

7. Thacher TD, Fischer PR, Pettifor JM, Lawson JO, Manaster BJ \& Reading JC (2000) Radiographic scoring method for the assessment of the severity of rickets. J Trop Pediatr 46, $132-139$.

8. Agricultural Extension and Research Liaison Services (1985) Food composition table for use in Africa. In Soyabeans in the Nigerian Diet, p. 62. Zaria, Nigeria: Ahmadu Bello University.

9. National Research Institute for Nutritional Diseases (1986) NRIND Food Composition Tables, 2nd ed. [E Gouws and ML Langenhoven, editors]. Parow: South African Medical Research Council.

10. Abrams SA (1999) Using stable isotopes to assess mineral absorption and utilization by children. Am J Clin Nutr $\mathbf{7 0 ,}$ 955-964.

11. Heaney RP, Weaver CM \& Fitzsimmons ML (1990) Influence of $\mathrm{Ca}$ load on absorption fraction. J Bone Miner Res 5, $1135-1138$.

12. O'Brien KO, Abrams SA, Liang LK, Ellis KJ \& Gagel RF (1996) Increased efficiency of $\mathrm{Ca}$ absorption during short periods of inadequate $\mathrm{Ca}$ intake in girls. Am J Clin Nutr 63, 579-583.

13. Heany RP, Saville PD \& Recker RR (1975) Calcium absorption as a function of Ca intake. J Lab Clin Med 9, 881 .

14. Bronner F \& Pansu D (1999) Nutritional aspects of Ca absorption. J Nutr 129, 9-12.

15. Wastney ME, Martin BR, Peacock M, Smith D, Jiang XY, Jackman LA \& Weaver CM (2000) Changes in Ca kinetics in adolescent girls induced by high $\mathrm{Ca}$ intake. J Clin Endocrinol Metab 85, 4470-4475.

16. Ames SK, Gorham BM \& Abrams SA (1999) Effects of high compared with low $\mathrm{Ca}$ intake on $\mathrm{Ca}$ absorption and incorporation of iron by red blood cells in small children. Am J Clin Nutr 70, 44-48.

17. Abrams SA, Griffin IJ, Hicks PD \& Gunn SK (2004) Pubertal girls only partially adapt to low dietary $\mathrm{Ca}$ intakes. J Bone Miner Res 19, 759-763.

18. Abrams SA, O’Brien KO, Liang LK \& Stuff JE (1995) Differences in $\mathrm{Ca}$ absorption and kinetics between black and white girls aged 5-16 years. J Bone Miner Res 10, 829-833.

19. Abrams SA, Griffin IJ, Hawthorne KM, Gunn SK, Gundberg CM \& Carpenter TO (2005) Relationships among vitamin D levels, parathyroid hormone, and $\mathrm{Ca}$ absorption in young adolescents. J Clin Endocrinol Metab 90, 5576-5581.

20. Lee WTK, Leung SSF, Fairweather-Tait SJ, et al. (1994) True fractional $\mathrm{Ca}$ absorption in Chinese children measured with stable isotopes $\left({ }^{42} \mathrm{Ca}\right.$ and $\left.{ }^{44} \mathrm{Ca}\right) . \mathrm{Br} J$ Nutr 72, 883-897.

21. Lee WTK, Leung SSF, Xu YC, Wang SH, Zeng WP, Lau J \& Fairweather-Tait J (1995) Effects of double-blind controlled $\mathrm{Ca}$ supplementation on $\mathrm{Ca}$ absorption in Chinese children measured with stable isotopes $\left({ }^{42} \mathrm{Ca}\right.$ and $\left.{ }^{44} \mathrm{Ca}\right) . \mathrm{Br} J \mathrm{Nutr} \mathbf{7 3}$, 311-321. 